\title{
Preliminary Approach Regarding Eastern and Western Christian Churches in Medieval Maramureș County
}

\author{
IOANA POP
}

The present research investigates the presence and coexistence of two denominations, the Western and Eastern Christian faith, in medieval Maramures county. For this, a close analysis of medieval published documents was performed. Along with these primary sources, the historiography of the subject was also consulted. The survey shows that both denominations were well-represented both institutionally and through active members, even if measures were taken by the bishops of Rome and kings of Hungary against the Eastern Christian faith in the realm. We hope that future archival and archaeological research will lead to new findings that will contribute to a better understanding regarding the historic coexistence of the two denominations in Maramures, County.

Keywords: Maramures, County, Western Christian Church, Eastern Christian Church, Peri, Pauline Order, Remeți, salt mining, settlers

The first Hungarian king, Stephen I (1000-1038) passed on to his son, Emeric, and through him, to all his heirs Nam unius linguae uniusque moris regnum imbecille et fragile est. He stressed the need to increase the number of inhabitants of the Kingdom of Hungary to achieve stability in the frontier area of Latin Christianity. ${ }^{1}$ The existence of inhabitants that had different mother tongues and ethnicities led, implicitly, to the coexistence of several denominations, and the kings of Hungary were aware of this. The fact that the majority of Romanians were considered schismatic was by no means foreign to them. The religious tolerance practiced by the kings was due to the following factors: the large number of Eastern Christians in the region and the position of Hungary between the Byzantine and the Holy Roman Empire. ${ }^{2}$

\footnotetext{
* Ioana-Terezia Pop, librarian at "Octavian Goga" County Library Cluj-Napoca, 104 Calea Dorobanților, 400609, Cluj-Napoca, Romania, ioana.t.pop@gmail.com.

${ }^{1}$ János M. Bak, "Linguistic Pluralism in Medieval Hungary," in The Culture of Christendom: Essays in Medieval History in Commemoration of Denis L.T. Bethel, ed. Marc Anthony Meyer (London: Hambledon Press, 1993), 269; Nora Berend, "Hungary, "the Gate of Christendom»," in Medieval Frontiers: Concepts and Practices, eds. David Abulafia, Nora Berend (Aldershot: Ashgate, 2002), 195-215.

2 Șerban Papacostea, Geneza statului în evul mediu românesc: studii critice (București: Corint, 1999), 223.
} 
Another aspect is the military importance that the Christians of Eastern rite (Romanians, Serbs or Bulgarians) had, and whose military merits could not be disputed; they were the ones who had defended the southern and south-eastern borders of the kingdom, in the face of the Ottoman peril in the fifteenth and sixteenth centuries. ${ }^{3}$ During the Middle Ages, several measures were taken by the Hungarian royalty in matters of religious affiliation. However, catholicisation was difficult to implement in districts that remained predominantly faitfull to the Eastern Church (and populated by a majority of Romanians); in these areas, measures have been reduced due to the preservation of local traditions. ${ }^{4}$ Here we refer to Maramureș County, but also Banat and Hațeg. This paper aims to immerse into an interesting aspect happening in Maramureș ${ }^{5}$ in the period of the fourteenth to sixteenth centuries, namely the coexistence of the Western and Eastern denominations. Therefore, two aspects will be pursued: the presence of the Eastern Christian Church in Maramureș County and the role played by Peri Monastery and, the existence of the Western Christian Church and the connection with the settlers.

The present research is based on collections of medieval charters, published both in Romania and abroad, but also on the relevant historiography for the subject. The documents were made, as we shall see, by places of authentication, county and town authorities, kings of Hungary, bishops of Rome and default ecclesiastical institutions. Due to the sources used, the

\footnotetext{
${ }^{3}$ Ioan-Aurel Pop, Națiunea română medievală (București: Editura Enciclopedică, 1998), 91.

${ }^{4}$ Ibidem, 94. For protection measures taken by kings Matthias or Vladislav II for Romanians see Ioan-Aurel Pop, „Din mâinile valahilor schismatici...” "românii și puterea în Regatul Ungariei medievale (Cluj-Napoca: Școala Ardeleană, 2011), 457-58 and 461-62. Despite the catholicisation led by the kings of Hungary (due to political pragmatism), only a third of the Kingdom's population adopted the religion of Rome. Even after the middle of the fourteenth century, most Romanian nobles remained East christians, and their Church, despite the pressures and measures against it, continued its existence. However, the Romanian elites (a small part of the Romanian mass of the realm) followed a different trajectory, they adopted the confessional color of the rulers. Holy Roman Emperor Sigismund of Luxembourg confirms in 1428 a measure taken by King Louis I of Hungary in 1366, namely landowners could be only from the Western Church. Documenta Romaniae Historica C, XIII (București: Editura Academiei Române, 1994), doc. 5. Another privilege of Louis I of Anjou from June 28, 1366, allows the nobles to win the case in any trial in which Romanians prove to be guilty. The privilege must be seen in the light of the time when King Louis I had offered privileges to cities and nobility, namely the privileged decision-makers group in the Transylvanian voivodeship. Ioan-Aurel Pop, "Un privilegiu regal solemn de la 1366 și implicațiile sale", Mediaevalia Transilvanica vol. I, no. 1-2 (1997): 69-85 and DRH, C. Transilvania XIII (1366-1370), doc. 92.

${ }^{5}$ Medieval Maramureș County had an area of $10.354 \mathrm{~km}^{2}$. The territory southwest of the Tisza River, on which the present study is based, comprises less than half of the former county and today is part of Romania. The other part of the former county, the northeastern, is nowadays in Ukraine. In 1920 Romania’s border was fixed on the Tisza riverbed, from that moment on one-third of the medieval county belonged to Romania.
} 
limitation of the paper is that it is based only on published charters. A future, thorough analysis of unpublished sources is desired.

Before delving into the subject a terminological clarification is required. ${ }^{6}$ Terms such as "Catholic" and "Orthodox" are names adopted in the sixteenth century, after the Council of Trent (1545-1563). The most appropriate description for them in the Middle Ages would be "Western faith" and "Eastern faith," or "Roman faith" and "Byzantine faith." Moreover, the faith of the Romanians living in Transylvania was called "Wallachian faith," which meant that instead of Orthodox one may encounter the term valah (Wallachian). In this paper, the term Eastern Church will be applied when referring to the Orthodox Church, and Western Church will be used for the Latin or Catholic Church.

\section{The Eastern Church in Maramureș County}

The papacy involved the Hungarian kings in converting the subjects who were under the jurisdiction and administrative borders of the kingdom. This universalist vision, which the Bishops of Rome had in mind, was not fully transposed into the reality of the territory. ${ }^{7}$ The presence of dwellers of Eastern faith is well known, as it can be seen in the customs of the realm: preterea quidam sunt Volachi et Rutheni, quidam autem Rasciani sive Serviani et Bulgari grecorum sequentes errores. ${ }^{8}$ Thus, in the Middle Ages, there were two attitudes toward the schismatics, one of violent intervention through decrees for the catholicisation of all the inhabitants, ${ }^{9}$ and another of tolerance due to the involvement of the Romanians, Serbs, and Ruthenians in the anti-Ottoman campaigns and due to the religious union established following the Council of Ferrara-Florence (1438-1439). ${ }^{10}$ This tolerance brought

\footnotetext{
${ }^{6}$ To better understand this terminological issue Pop, "Din mâinile valahilor schismatici...", 35-37 and 373-74.

${ }^{7}$ Ioan Drăgan, Nobilimea românească din Transilvania între anii 1440-1514 (București: Editura Enciclopedică, 2000), 99-100.

${ }^{8}$ János M. Bak, Péter E. Banyó, Martyn Rady, eds., The Laws of the Medieval Kingdom of Hungary, vol. 5. The Customary Laws of the Renowned Kingdom of Hungary. A Work in Three Parts Rendered by Stephan Werböczy (The "Tripartitum") (Budapest: Central European University, 2005), III 25:1.

${ }^{9}$ Bans imposed on schismatic priests and measures taken against the East christians Monumenta vaticana historiam regni Hungariae illustrantia, IX. Bonifácz pápa bullái 13961404 ser. I, tom 4 (Budapest, 1889), doc. 150, 222, 463. Adrian Andrei Rusu, Izvoare privind Evul Mediu Românesc: Ţara Hategului în secolul al XV-lea (1402-1473) (Cluj-Napoca: Dacia, 1989), doc. 59, 68, Eudoxiu de Hurmuzaki, Documente privitoare la istoria românilor, vol. I, part 2, 1346-1450 (București: Stabilimentulu graficu Socecu \& Teclu, 1890), doc. 481.

${ }^{10}$ The union following the Council of Ferrara-Florence was nevertheless ephemeral. Drăgan, Nobilimea românească, 100-103. For the importance of the Wallachians in the thirteenth
} 
for the Romanian nobility church renaissance, the development of the noble status, the acceptance of a Romanian episcopate, and for the Hungarian royalty, it was supported in pursuing royal interests. ${ }^{11}$

Since the Eastern Church was subject to the institutional forms of feudalism its hierarchy and organization also depended on local circumstances. ${ }^{12}$ In the nineteenth century, the historian Szilágy Sándor perceived one of the purposes of the kneazes: the defence of their religion and the establishment of an independent institution. ${ }^{13}$ Although restrictive measures were taken for the Romanian kneaz and there were conflicts with the settlers, as we will see, still few Maramureș residents from rural settlements switched to the Western Church. The descendants of Drag, the son of Sas voivode, are among the few who converted; in consequence Drag's son, Gheorghe changed his name to Emeric, and his nephew Bartolomeu Drágfi became voivode of Transylvania (1493-1499)..$^{14}$

The Bishopric of Halych was founded in the twelfth century and at the beginning of the fourteenth century it received the title of Metropolis. It was abolished in 1347 and submitted, through the Metropolis of Kiev, to the Patriarchate of Constantinople; this was the ecclesiastical institution that had jurisdiction over the Eastern Christians of Maramureș county between the twelfth and fourteenth centuries. ${ }^{15}$ Since Sigismund, Holy Roman Emperor, King of Hungary and Bohemia (1387-1437) didn't want to establish an exarchate dependent on the patriarchy of Constantinople, the Romanian voivodes resorted to the solution of founding an exarchate for the Eastern Christians from Sălaj, Mediaș, Ugocea, Bârjava, Ciceu, Maramureș,

century campaigns against the Mongol attacks see Șerban Papacostea, Românii în secolul al XIII-lea între cruciată și Imperiul mongol (București: Editura Enciclopedică, 1993), 136-38.

${ }^{11}$ Drăgan, Nobilimea românească, 104. See also Adrian Andrei Rusu, Ioan de Hunedoara și românii din vremea sa (Cluj-Napoca: Presa Universitară Clujeană, 1999), 110.

${ }^{12}$ Ioan-Aurel Pop, „Confesiune și națiune medievală: solidarități românești în secolele XIVXVI," Anuarul Institutului de Istorie și Arheologie Cluj-Napoca, series Historia no. XXVIII, (1987-1988): 177.

${ }^{13}$ Szilágy Sándor, Erdélyország története tekintettel mivelödésére vol. I (Pesta: Heckenast Gusztáv, 1866), 122 apud Pop, „Confesiune și națiune medievală,” 178.

${ }^{14}$ Ștefan Lupșa, Catolicismul și românii din Ardeal și Ungaria până la anul 1556 (Cernăuți: Institutul de Arte Grafice și Editură Glasul Bucovinei, 1929), 77.

${ }^{15}$ Pr. Ioan M. Bota, „Mănăstirea Peri-Maramureș și rolul ei în istoria culturii românești,” Maramureș. Vatră de istorie milenară 2 (1997): 75; Radu Popa, Țara Maramureșului în veacul alXIV-lea (București: Editura Enciclopedică, 1997), 204 and Șerban Andreescu, „Mitropolia de Halici și episcopia de Asprokastron. Câteva observații,” in Național și universal în istoria românilor: Studii oferite prof. dr. Şerban Papacostea cu ocazia implinirii a 70 de ani, eds. Gheorghe Lazăr, Ovidiu Cristea and Șerban Papacostea (București: Editura Enciclopedică, 1998), 126. 
and Bihor. Balc and Drag, the voivodes of Maramureș, who, being subjects of the kingdom, could not ask for an exarchate, but as founders demanded the stavropegial right for the monastery they inherited. ${ }^{16}$ Also, in 1387 Halych was incorporated into Poland, thereby losing jurisdiction over the Eastern Christians in Hungary; this was one of the reasons why the lords wanted the creation of a stavropegia. ${ }^{17}$

From the end of the fourteenth century, the northeastern part of the Kingdom of Hungary entered into the jurisdiction of the Peri monastery. Today, in Hrushovo (Ukraine) one can see only the ruins of Saint Michael Monastery, as the religious edifice was destroyed in the eighteenth century. It is believed that the name "Peri" (pears) comes from the pear trees that grew there in large numbers. ${ }^{18}$ To commemorate the historical importance of Peri Monastery in the Romanian town of Săpânța (the Săpânța-Peri monastery) another monastery was built in approximately 2000. Viewing this monastery, Radu Popa claimed that the building that Balc and Drag had inherited, one of small size and made of wood, would have been replaced with one of stone, to match its importance. ${ }^{19}$ Due to the collaboration between the County Museum of Satu Mare and the Uzhhorod National University, two archaeological excavations were carried out respectively on July 6-18 and September 15-20, 1998. Following these excavations, the building that stands in the place of the old monastery (in Ukraine) was dated between the sixteenth and seventeenth centuries. Consequently, subsequent archeological campains could bring to light more evidence regarding the medieval monastery. ${ }^{20}$

The first known mention so far, about the monastery, can be found in the report done by Lelesz Convent on February 2, 1389, which stated the

\footnotetext{
${ }^{16}$ Mircea Păcurariu, „Mănăstirea «Sfântul Mihail» din Perii Maramureșului - la 600 de ani de la prima atestare documentară," Ortodoxia maramureșeană 2, no. 2 (1997): 159 and Alexandru Filipașcu, Istoria Maramureșului (Baia Mare: Editura Gutinul, 1997), 57.

${ }^{17}$ Filipașcu, Istoria Maramureșului, 57; Bota, „Mănăstirea Peri-Maramureș,” 76; Popa, Țara Maramureșului, 204 and Șerban Andreescu, „Mitropolia de Halici și episcopia de Asprokastron. Câteva observații," in Lazăr, Cristea and Papacostea, Național și universal în istoria românilor, 131-32.

${ }^{18}$ Păcurariu, „Mănăstirea «Sfântul Mihail» din Perii Maramureșului,” 157. For the etymology of the term see: Vasile Bologa, „Mănăstirea Peri - ipoteze etimologice,” Maramureș. Vatră de istorie milenară 3 (1997): 57, especially the testimony of Ioan Marina.

${ }^{19}$ Popa, Țara Maramureșului, 214.

${ }^{20}$ Adrian Andrei Rusu, „Mănăstirea Peri (Hrușevo, Ucraina) Elemente preliminare noi privitoare la istoria și arheologia ei," Relații româno-ucrainene, istorie si contemporaneitate no. 1 (January, 1999): 169-74, also the results of the two campaigns http://cronica.cimec. ro/detaliu.asp?k=534 and http://cronica.cimec.ro/detail.asp?k=1669, accessed November 19, 2020.
} 
redrawing of Drag's estates, the comes of the Szeklers. In this report, a monastery was recorded at the borders of Taras. ${ }^{21}$

The following mention is from August 13 (14), 1391, from Anthony the patriarch of Constantinople. ${ }^{22}$ At that moment, at Drag's request, the patriarch took the monastery that Balc and Drag inherited under his protection. The monastery received from Balc's sons, Dumitru and Alexandru, according to a document from May 1, 1404, three villages and a mill. ${ }^{23}$ The Peri Monastery benefits from a reordination of its estate, Kertveles (Peri), at the request of the monks in 1438; then, the estate was distinguished from the neighbouring estates of Taraczkoz, Câmpulung la Tisa, and Apșa. ${ }^{24}$ Another favour was received for the monastery in 1442 according to two records: the first one by King Vladislav I of Hungary (1440-1444), and the second was a response to the royal mandate from the Chapter in Oradea. These documents were perceived as echoes of the ephemeral union of Ferrara-Florence due to the Romanians who received property through a new donation charter. ${ }^{25}$

From the mandate made by King Ladislaus the Posthumous (1440 1457) on April 6, 1456, and from the report from the Lelesz convent on June 10, 1456, one can find out an issue regarding the delimitation of the city Câmpulung la Tisa. Thus, the nobles from Săpânța and Sarasău and, secondly, Simon the monk from Saint Michael, complain that the magistrate of Câmpulung la Tisa pushed the boundaries of the city. So they violated the property of the monastery, which was located nearby. ${ }^{26}$ The process can be tracked over time. In 1458 the defendants were returned to the possession of their estates between Sarasău and Săpânța. ${ }^{27}$ An important element

${ }^{21}$ Ioan Mihlayi de Apșa, Diplome maramureșene din secolele XIV și XV, ed. IV (Cluj-Napoca: Editura Societății Culturale Pro Maramureș „Dragoș Vodă”, 2009), doc. 53. Buștina, Bubășari, Voinești, Taras, Teceu Mic, Teceu Mare and Talabor are situated in Ukraine and Câmpulung la Tisa in Romania, on the border with Ukraine.

${ }^{22}$ Mihalyi, Diplome maramureșene, doc. 62. According to the copy of the document from fourteenth May 1494 issued by King Vladislav and which contains in transumpt the document made by Antony, the patriarch of Constantinople, in 1391, from the register SJAN Sibiu, Fond Colectria de acte fasciculate, Seria G. Probleme religioase, no. 1, f. 1-3 but also from Magyar Országos Levéltár, Budapest, Diplomatikai Levéltár. (DL) 226520 the date of the document is August 14, 1391, as in the transumpt from DL 36886.

${ }^{23}$ Nicolae Iorga, „O mărturie din 1404 a celor mai vechi «moldoveni ", in Studii asupra evului mediu românesc, ed. Șerban Papacostea (București: Editura Științifică și Enciclopedică, 1984), 155-57.

${ }^{24}$ Mihalyi, Diplome maramureșene, doc. 178.

${ }^{25}$ Marius Diaconescu, "Les implications confessionnelles du Concile de Florence en Hongrie," Mediaevalia Transilvanica 1, no. 1-2 (1997): 34-35, documents reported by Marius Diaconescu: DL 13687, 13688.

${ }^{26}$ Mihalyi, Diplome maramureșene, doc. 226 (222).

${ }^{27}$ Ibidem, doc. 238. 


\section{Ioana Pop}

for the eastern priests from Maramureș was the decree made by Matthias, King of Hungary (1458-1490), on March 20, 1479, at the request of the Metropolitan of Belgrade ${ }^{28}$. In the document, it is stated that Romanian priests "who hold the Greek faith" in Maramureș County are tolerated and exempted from paying taxes. Another element of conflict and positive intervention from the Hungarian royalty in favour of the local nobles can be found in the 1480 report of the Cluj-Mănăștur Convent following the order of Matthias Corvinus. ${ }^{29}$ The research carried out by the convent shows that the defendants' John, together with his wife Catherina and their son Thomas, were damaged in the personal estate Bocicoiul Mare and Lunca la Tisa by Peter of Dej, the comes of Maramureș. The damage consisted of the destruction of the Bocicoiul Mare parish church.

The conflict in which the monastery from Peri was involved continued with John, the Ruthenian bishop of Mukachevo, who wanted to accumulate as many goods as possible, but also to limit the scope of action of the abbot of Peri. Therefore, Bishop John forged a document in 1360 in which he replaced the name of the monastery of St. Nicholas with that of the Archangel Michael. By this, he obtained from Vladislav II, King of Hungary (1490-1516) the revenues of the Peri Monastery, but in response to this action, Ilarie the abbot of Peri shows the king the tomos from 1391, with the help of which he is restored to his rights. ${ }^{30}$ Following this event, Vladislav II of Hungary transcribed and strengthened on May 14, 1494, to the exarch of Peri the rights he had from the time of Antony the patriarch of Constantinople. ${ }^{31}$ Following the king's decree of 1494, the abbot of Peri was instructed to have a proper relationship with the bishop of Mukachevo and to show obedience to the bishop of Transylvania, who most likely was the one from Feleac. ${ }^{32}$ According to the record from the same Hungarian king on November 29, 1498, because Bishop John of Mukachevo did not fulfil the word of the previous decree, the king was forced to ask the magistrate of Maramureș County to protect Ilarie, the abbot, in his rights. ${ }^{33}$

${ }^{28}$ Ibidem, doc. 313, see also the copy of the document in the register SJAN Sibiu, Fond Colectria de acte fasciculate, Seria G. Probleme religioase, no. 1, f. 1-3.

${ }^{29}$ Mihalyi, Diplome maramureșene, doc. 318.

30 Păcurariu, „Mănăstirea «Sfântul Mihail» din Perii Maramureșului,” 160 and Mihalyi, Diplome maramureșene, doc. 348 for two documents issued in July 31, 1491 (see also the copy from SJAN Sibiu, Fond Colecția de acte fasciculate, Seria G. Probleme religioase, nr. 1, f. 1-3.) respectively March 8, 1360.

${ }^{31}$ Mihalyi, Diplome maramureșene, doc. 352.

32 Păcurariu, „Mănăstirea «Sfântul Mihail» din Perii Maramureșului,” 161.

${ }^{33}$ Mihalyi, Diplome maramureșene, doc. 360 și Păcurariu, „Mănăstirea «Sfântul Mihail» din Perii Maramureșului," 161. See also the copy of the document in the register SJAN Sibiu, Fond Colecția de acte fasciculate, Seria G. Probleme religioase, no. 1, f. 1-3. 
Studies regarding the documents about Peri Monastery considered the consecration act from 1391 a factor in consolidating the Eastern community in the Kingdom of Hungary, but also the maintenance of the Eastern faith and local elements in the face of restrictive measures and changes coming from the royalty. ${ }^{34}$ Among the studies, an ephemer unionist mark was recognized due to the wave of Western missionaries who made their influence in culture and connected with the Council of Ferrara-Florence (1438-1439). ${ }^{35}$

From the analysed data it appears that the charter from 1391 was a beneficial element both for the Maramureș inhabitants of Eastern faith and for the Hungarian royalty, which kept in this county a balance following the revolt led by the voivode Bogdan. However, the Peri Monastery meant the consolidation of the Slavonic faith and culture for the county of Maramureș. Also, towards the middle of the fifteenth century, but also in the following decades, the tolerant attitude of the Hungarian royalty was felt due to the positive attitude shown towards the Romanian nobility, like in the case of nobles against the inhabitants of the royal city Câmpulung la Tisa. Afterwards, we can mention the decree of exemption and tolerance for the Eastern faith priests, but also the support that came in the conflict with the bishop of Mukachevo. As to the consequences (and compromises) of the Council of Ferrara-Florence, in terms of the religious tolerance enjoyed by Eastern Christians in Maramureș county, but also of the political interests that emerged, independent and thorough studies would be needed. If we look carefully at the records from in the fourteenth and fifteenth centuries, the priests, as nobles, took part in the county's events and the churches are

\footnotetext{
${ }^{34}$ Grigore Nadiș, „Despre mănăstirea din Peri,” Graiul românesc II, no. 2 (1928): 21-26; Ioan Lupaș, „Din trecutul românilor maramureșeni,” Graiul românesc I, no. 4 (1927): 81-83; Vasile Bologa, „Mănăstirea Peri - ipoteze etimologice,” Maramureș. Vatră de istorie milenară vol. III (1997): 57-60; Valer Hossu, „Stavropighia Perilor în contextul luptei drăgoșeștilor maramureșeni pentru revenirea în scaunul Moldovei," Maramureș. Vatră de istorie milenară vol. II (1997): 91-94; Zenovie Pâclișanu, „Câteva contribuții la istoria mănăstirii din Perii Maramureșului," in Inchinare lui Nicolae Iorga cu prilejul implinirii vârstei de 60 de ani, ed. Ștephan Metesș (Cluj: Editura Institului de Istorie Universală, 1931), 333-35; Vasile, episcopul Oradiei, „Din trecutul Bisericii Ortodoxe Române - rolul mănăstirii din Perii Maramureșului,” Mitropolia Ardealului XXIII, no. 1-3 (January-March, 1978): 13-19; Damaschin CoravuSeverineanul, „Mănăstirea din Peri și importanța sa istorică,” Mitropolia Olteniei XXXIV, no. 7-9 (July-September, 1982): 496-514; Viorica Ursu, „S, Sase secole de la atestarea documentară a mănăstirii «Sfântul Mihail» din Peri - Maramureș ca stavropighie patriarhală. Expoziție de istorie și artă veche religioasă-catalog. Simpozion științific,” Marmația 7, no. 2 (2002): 227-42; Păcurariu, „Mănăstirea «Sfântul Mihail» din Perii Maramureșului,” 155-165.

35 Bota, „Mănăstirea Peri-Maramureș și rolul ei,” 74-83; Diaconescu, "Les implications confessionnelles du Concile de Florence,” 29-61, Rusu, Ioan de Hunedoara și românii, 77-127 and Dorinel Dani, „Ortodocșii ruși și români la sinodul Unionist de la Ferrara-Florența (1438-1439)," Ortodoxia Maramureșeană VI, no. 6 (2001): 179-94.
} 
an important reality present in charters. ${ }^{36}$ The religious reality overlapped with zonal conduct according to the desires of the local nobles, following the supervision of the Hungarian royalty.

\section{The Western Church in Maramureș County}

The first pieces of information regarding Maramureș are those that mention the presence of the Western Church. At the end of the thirteenth century, Germans and Hungarians (the latter most probably coming from the neighbouring county of Ugocsa) came ${ }^{37}$ and settled in Hust, Visc, Teceu, Câmpulung la Tisa, and Sighet. As a consequence, Western churches were built for this minority.

The jurisdiction over Maramureș, a borderland county, lead to disputes between the bishoprics of Eger (Agria) and Transylvania (based in Alba Iulia). The territory should have been, from a secular point of view, under the jurisdiction of the latter due to the archbishopric of Sásvár (Ugocsa), the old county of Sásvár included also Maramureș. However, when the West Christians settled in Maramureș they attracted the interest of the bishop of Eger who asked King Andrew III (1290-1301) to place the area under his jurisdiction, ${ }^{38}$ at the expense of its Transylvanian counterpart. Two documents

\footnotetext{
${ }^{36}$ Documentary evidence of the existence of monasteries are for Bârsana, Cuhea (today Bogdan Vodă); churches Bocicoiul Mare, Cuhea, Giulești and Sarasău; priests Cosău, Cuhea, Giulești, Săliște, Virișmort (today Tisa) and Vișeu. Mihalyi, Diplome maramureșene, doc. 26, 61, 99, 150, 229(230), 295(293), 318, 323, Ioan Aurel Pop, ed., Diplome maramureșene din secolele XVI-XVIII, provenite din colecția lui Ioan Mihalyi de Apșa (București: Editura Academiei Române, 2010), doc. 79, 172, 173, 179, 326. For archaeological findings related to stone churches from Maramureș Radu Popa, Mircea Zdroba, Șantierul arheologic Cuhea. Un centru voievodal din veacul al XIV-lea (Baia Mare: Muzeul Regional Maramureș, 1966); Radu Popa, Cnezatul Marei (Baia Mare: Muzeul Judeţean Maramures, 1969); Radu Popa, „Biserica de piatră din Cuhea și unele probleme privind istoria Maramureșului în secolul al XIV-lea," Studii si cercetari de istorie veche 17, no. 3 (1966): 511-28; Radu Popa, Mircea Zdroba, „Ctitoria cnezilor giuleșteni. Un nou monument românesc din piatră în Maramureș,” Studii si cercetari de istorie veche 20, no. 2 (1969): 267-85; Radu Popa, „Noi cercetări de arheologie medievală în Maramureș. Șantierul Sarasău," Studii si cercetari de istorie veche 22, no. 4 (1971): 602-24; Alexandru Baboș, „Mândria Giuleștiului de altă dată, beserica sa de petra care n'are socia în giuru," Acta Musei Maramoroseinsis no. 1 (2002): 267-88; Alexandru Baboș, „Un martor al Maramureșului medieval, biserica de piatră din Sarasău," Anuarul Muzeului Etnografic al Transilvaniei (2002): 703-21.

${ }^{37}$ Gulyás László Szabolcs, Városfejlödés a középkori Máramarosban (Cluj-Napoca: Erdélyi Múzeum-Egyesület, 2014), 147. This settlers and their five cities recieved in the fourteenth and fifteenth century privileges from the kings and queens of Hungary. Mihalyi, Diplome maramureșene, doc. 4, 223, 299 and 356.

${ }^{38}$ Hegyi Géza, “Egyházigazgatási határok a középkori Erdélyben,” Erdélyi Múzeum 72, no. 3/4 (March, 2010).
} 
from 1299 (February 19 and August 10) and one from $1300^{39}$ introduce the dispute. In this trial, the bishop of Eger is accused of consecrating cemeteries in several places in Maramureș. According to the diploma from January 6, 1300, the bishop also collected tithes from the county. Charters issued in the fourteenth century highlight that the bishopric of Eger received jurisdiction over the county. Documents from 1331-1333 mention a clergymember listed as George, archdeacon of Maramureș, as a member in the list of dignitaries made by the chapter of Eger, but also as a participant in reconciliation processes between nobles. ${ }^{40}$ Moreover, in the papal tithe registers of 1332 1337, the five parishes from Maramures, and even the area of Nagybánya and Meggyes in Satu Mare, appear in the diocese of Eger. ${ }^{41}$ The record shows that Michael, a priest and magistrate of the altar of St. Emeric Church of Sighet was the person sent, in 1353, by the chapter of the church in Eger to accomplish the mandate of King Louis for Stephen and John, sons of Iuga Voivode, to take possession of an estate. ${ }^{42}$ Furthermore, in 1346 Benedict, the rector of Sighet and vicar of Maramures, together with George, rector of the parish church of Visc, promised obedience to the bishop of Eger and they both condemned the interference of the episcopate of Transylvania. ${ }^{43}$

Even though the issue of spiritual jurisdiction over West Christians in Maramureș County remains an open problem, a few observations can be emphasized. The county was most likely included in the spiritual care of the Diocese of Eger, because the papal titles from Maramureș are registered within this diocese and, one of its capitulars is an archdeacon from Maramureș. ${ }^{44}$ Although in the fifteenth and sixteenth centuries, Maramureș

\footnotetext{
${ }^{39}$ Documente privind Istoria României C. Transilvania, veacul XIII, vol. 2 (București: Editura Academiei Republicii Populare Române, 1952), doc. 503, 510; respectively doc. 521, Mihalyi, Diplome maramureșene, doc. 1.

${ }^{40}$ DIR C. Transilvania, veacul XIV, vol. 3, 1954, doc. 1, 57 and 127.

${ }^{41}$ Pavel Binder, „Contribuții la studiul dezvoltării feudalismului în Maramureș și în nordul Transilvaniei," Studii si articole de istorie 10 (1967): 44; see also DIR, veacul XIV, vol. 3, 248-52, doc. 56. The Archdiocese of Maramureș also included territories from the following counties: Sătmar, Ugocea and Bereg. Géza, "Egyházigazgatási határok a középkori Erdélyben," 3.

${ }^{42}$ Mihalyi, Diplome maramureșene, doc. 16.

${ }^{43}$ Jakó Zsigmond, Kovács W. András and Hegyi Géza, eds., Codex diplomaticus Transsylvaniae. Diplomata, epistolae et alia instrumenta litteraria res Transsylvanas illustrantia. Erdélyi okmánytár. Oklevelek, levelek és más irásos emlékek Erdély történetéhez. III (1340-1359) (Budapest: Magyar Országos Levéltár, 2008), doc. 336; DIR, C. Transilvania, veac XIV, vol. 4, 1955, doc. 440, Mihalyi, Diplome maramureșene, doc. 12, György Fejér, Codex diplomaticus Hungariae ecclesiasticus ac civilis tom IX, vol. 1 (Budae: Typis typogr. Regiae Vniversitatis Vngaricae, 1833), doc. 241.

${ }^{44}$ DIR, C, veac XIV, vol. III, doc. 1, doc. 57, 127.
} 
was under the jurisdiction of the Diocese of Eger, it is possible that before or during this chronological interval the Diocese of Transylvania took over for a short period. It is considered that initially, Maramureș was part of a vicariate together with Bereg and Ugocea, but in the first decades of the fourteenth century, there was an archdeaconry of Maramures, within the Diocese of Eger. According to the tithe registers from 1334, this also included churches from Ugocea and Sătmar counties. ${ }^{45}$ After 1340 the structure of the church in Maramureș was reorganized into a vicariate only for the county churches, while the vicars resided in the city of Hust. ${ }^{46}$

The first Western church in Maramureș County was founded in Visc (dedicated to St. Nicholas). Then, in Hust were located the most (the oldest was dedicated to Blessed Elizabeth, the vicar of Maramureș resided there; other churches were dedicated to St. Catherine, the Holy Cross, the Blessed Virgin Mary, St. Stephen the King, Michael the Archangel and All Saints). In Câmpulung la Tisa there was a church dedicated to St. Martin and in Sighet a parish church dedicated to St. Emeric. ${ }^{47}$ Regarding a Benedictine abbey at Hust, there is only late information; according to these documents, in the middle of the sixteenth century, the monks of St. Helena's church were expelled due to the Reformation. ${ }^{48}$

A relevant element in the county where the salt mines. Their income influenced the development of local towns, but they also played a very significant role in the history of the Hungarian kingdom. In Maramureș, the mining process began in the fourteenth century. The core of the administrative activity was at Hust, where the salt chamber was based, but there was also a subordinate chamber at Coștiui. ${ }^{49}$ For our topic, the salt mines are relevant due to the settlers that worked there. For their spiritual need, the priesthood of Sighet officiated their religious services in Coștiui and Rona de Sus. ${ }^{50}$

\footnotetext{
${ }^{45}$ DIR, C, veac XIV, vol. III, 248-49.

${ }^{46}$ The fortress of Hust had a strategic position being built during the reign of King Louis the Great. We have testimonies from 1450 and 1459 according to which the vicar from Maramureș, the parish priest of Hust, was called Simon. SJAN Maramureș, Familia Rednic, doc. 5 and Mihalyi, Diplome maramureșene, doc. 200(203).

${ }^{47}$ Diaconescu, „Biserica catolică din Maramureș,” 279-83.

${ }^{48}$ Ibidem, 284. The assumptions that there was a convent of the Order of Friars Minor are unfounded, there are no documents to attest it. Engel Pál, Regatul Sfântului Stefan. Istoria Ungariei medievale: 895-1526 (Cluj-Napoca: Editura Mega, 2006), 249; Livia Ardelean, Structuri social-economice în Maramureș între 1600-1700 (Baia-Mare: Editura ethnologică, 2012), 45.

${ }^{49}$ Jozsef Laszlovszky, Balázs Nagy, Péter Szabó and András Vadas, eds., The economy of medieval Hungary (Leiden and Boston: Brill, 2018), 183 and 205; Szabolcs, Városfejlödés a középkori Máramarosban, 148.

${ }^{50}$ The number of salt cutters assigned to Coștiui salt mine could not cope with the large amount of work so, often the help of the county's townspeople was called upon.
} 
In addition to the churches from the royal cities, an important element of Western faith was the Pauline monastery from Remeți. ${ }^{51}$ This was the only monastic order founded in the Kingdom of Hungary at the beginning of the thirteenth century. Pauline monasteries on the territory of today's Romania were built due to royal, papal, episcopal or nobles initiative, and the end of their existence was due to the incursion of the Turks, the Reform or some inconveniences from the founder's point of view, or from the voivodeship request. ${ }^{52}$ The period of existence of the Pauline Order (The Order of Saint Paul the First Hermit), on Romanian territory, on average is between the fourteenth century and the middle of the sixteenth century.

The founding of the monastery from Remeți can be linked to the establishment of new Pauline monasteries during the period of maximum expansion of the order in Hungary, in the fifth and sixth decades of the fourteenth century. Other information details that it belonged to the Diocese of Eger, it was endowed with privileges and donations from the Hungarian royalty and, by the middle of the sixteenth century, the place was abandoned..$^{53}$ During its existence, there is mention of a conflict, which spanned several years, with nobles from Sarasău and Săpânța, regarding the possession of some lands. Even if these nobles supported the Eastern monastery in Peri, a religious character cannot be given to this conflict. The problem of land was disputed even in the same nobiliary family (in these two villages), but we believe that any detail regarding the parties can be mentioned for a better outline of the event and the possibility of future discussions on the issue. The case was opened, between 1426 and 1430, by the nobles from Sarasău who complained that some of their land, situated in the vicinity of the monastery, had been stolen. ${ }^{54}$ In response, we have the intervention of Benedict, general of the Pauline Order, to Albert, King of Hungary, so that the nobles of the two mentioned villages would return a mill to the monks ${ }^{55}$. The conflict is present again between the two parties

${ }^{51}$ It is believed that it was built due to the initiative of Ludovic I, King of Hungary in 1363. Hurmuzaki, Documente privitoare la istoria românilor, doc. 62.

${ }^{52}$ Adrian Andrei Rusu, ed., Dicționarul mănăstirilor din Transilvania, Banat,Crișana și Maramureș (Cluj-Napoca: Presa Universitară Clujeană, 2000), 48, 94, 104, 142, 184, 192, 202, 203, 215-16, 226, 228, 230, 257, 259, 272, 284, Mihalyi, Diplome maramureșene, doc. $254(255)$.

${ }^{53}$ Marius Diaconescu, „Catolicismul în Maramureș (I) - Mănăstirea eremiților,” Satu Mare Studii și comunicări 14 (1997): 123-26 and 128-29.

${ }^{54}$ Mihalyi, Diplome maramureşene, doc. 156.

55 Gergely Gyöngyösi, Vitae fratrum eremitarum Ordinis Sancti Pauli primi eremitae (Budapest: Akadémiai Kiadó, 1988), 94 apud Diaconescu, „Catolicismul în Maramureș,” 127. 


\section{Ioana Pop}

in 1460 when the monks wanted to set again the border of their land towards Săpânța and Bedeu ${ }^{56}$. In response, the nobles opposed the new landmarks. On September 9, 1461, King Matthias demands to Lelesz Convent that the royal bailiff (homo regius) together with the witness of the convent should investigate again the cause between the nobles from Sarasău, Săpânța, and Slatina against the monks from Remeți. ${ }^{57}$ As the trial was delayed, on November 20, the same year, the king of Hungary ordered the county magistrate to do justice to the nobleman Peter Gherheș of Sarasău in his case against Michael Stibor from Sighet. ${ }^{58}$ The conflict continued in 1465, from this year a report of Lelesz Convent is kept, which includes the transumpt of a charter made by King Matthias, issued also in $1465 .{ }^{59}$ From the transumpt, we know about the nobles of Sarasău complaining regarding the misappropriation of land which belonged to the Săpânța estate and which started from a pond named Răchitiş and goes up to the monastery. The testimonies of the neighbours, abutter (commetaneus), and nobles from the same county (comprovincialis) from the report of Lelesz take the side of the nobles from Sarasău and Săpânța, and the sentence of the magistrate was for the monks to give an account of the violence brought to the Romanian nobles. The conclusion of this process is not clear from the following charters, but historian Marius Diaconescu provided two important references: the first one, from 1465, in which the general of the order is the one who reconciles the situation and draws again the boundaries of the monastery land, and the second is the inventory of the brothers' property from 1554, in which appears terra Reketye megy vocata a parte metae possessionis Zaploncza. ${ }^{60}$

As we could see St. Mary Monastery of Remeți was not a pillar of the Western faith in the county, but was certainly spiritual support for the royal cities, especially for Teceu, which was in its vicinity. And, surely, it was an element around which the village of Remeți was built.

\footnotetext{
${ }^{56}$ Mihalyi, Diplome maramureșene, doc. 250.

${ }^{57}$ The charter is available at Magyar Országos Levéltár, Budapest, Diplomatikai Fényképgyüjtemény. (DF) 222864. At Diaconescu, „Catolicismul în Maramureș,” 127 the document is dated August 8, 1464.

${ }^{58}$ Mihalyi, Diplome maramureșene, doc. 255(256).

${ }^{59}$ Ibidem, doc. 273(272).

${ }^{60}$ Diaconescu, „Catolicismul în Maramureș,” 127-28, 130. (The references given by the author are: Gergely Gyöngyösi, Vitae fratrum, 118 and from the annex to the article in the National Archives of Budapest, MKA, E 153, Acta Paulinorum, 27 cs., fasc. 206, f. 3-5).
} 


\section{Eastern and Western Christian Churches in Medieval Maramureș County: Final Considerations}

From the fourteenth to the sixteenth centuries, the coexistence of the Western and Eastern Churches is documented in Maramureș County. On the one hand, there are the communities of Western faith from the five royal cities. In addition, there is the community of salt cutters, from the settlers, that work in and around Coștiui Village and the Pauline monastery located in Remeți. On the other hand, there are the Romanians from the villages who remain faithful to Eastern precepts over the entire period studied.

Regarding the Eastern church in Maramureș, an important role had the two comes from the fourteenth century, Balc and his brother Drag. They appealed to the patriarch of Constantinople to grant for their monastery (from Peri) the right of stavropighie, which is directly linked to the patriarchy. Peri was an important center of Eastern faith in the eastern border of the Kingdom of Hungary. There are recorded misunderstandings between citizens and the magistrate of the royal city Câmpulung la Tisa and the monks from Peri, regarding the possession of some parts of land that belonged to the monastery. These trials end with the kings favouring the monks of Peri.

The organization of the Western Church in the county was, as seen, a necessary process after the dwelling of the settlers, at the end of the thirteenth century. The consequence of the settlers' settlement is the organization of the five royal cities (Hust, Visc, Teceu, Câmpulung la Tisa, and Sighet). The cities developed thanks to the presence of salt mines in the region and the interest of the kings to increase the kingdom's economy with their help. A community of Western faith was also founded at Coștiui because of the salt mines in the area. Western churches in the former medieval Maramureș County are still a minority (Coștiui, Vișeu de Sus, Borșa, Sighet, Câmpulung la Tisa, Ocna Șugatag and Bocicoiul Mare).

The Eastern faith is well-represented and in a majority in present-day Maramureș County, where almost every village currently has an Orthodox church. Therefore, this is one of the enclaves, in the Kingdom of Hungary, where catholicisation could not be imposed. Even if there were conflicts at the local level between members of the two confessions, the problems were solved, and often in favor of the local East christian nobles. In the end, one question remains, how much control could the kings, the Hungarian administrative apparatus, have over the confession of the population of the kingdom if they participated in the political interests of the former? 